\title{
LARVAL CULTURE OF NILE TILAPIA LINEAGES AT DIFFERENT STORAGE DENSITIES $^{1}$
}

\author{
EMÍLIA TATIANE LOPES DA SILVA², MARCELO MATTOS PEDREIRA ${ }^{2 *}$, GUILHERME DE SOUZA MOURA ${ }^{2}$, \\ DAIANE KELLY ALVES PEREIRA ${ }^{2}$, CARLOS JOSÉ OTONI ${ }^{2}$
}

\begin{abstract}
Larvae from two Nile tilapia (Oreochromis niloticus) lineages were subjected to different storage densities. An experiment was conducted arranged in a 4 x 2 factorial scheme, four storage densities $\left(6.25,12.50,18.75\right.$ and 25.00 larvae $\left.^{-1}\right)$ and two lineages (GIFT and Thai). Larvae from the lineage GIFT and Thai $(4,000)$ were distributed in 32 aquariums with 8 liters of water each, in a randomized order with four replications. The larvae were maintained in the aquariums with constant aeration and natural photoperiod for 36 days. Limnological variables were within the proper range to the specie. Data were subjected to ANOVA, and the Tukey test was used for the density effects. Regarding the biological variables, there was no interaction between lineage and density. The GIFT lineage presented better performance on total length and biomass at the $36^{\text {th }}$ day. Regarding the densities of each lineage, the greater length, weight and weight gain results were found with a density of 6.25 larvae $\mathrm{L}^{-1}$, however, an increase in biomass and a space use optimization occurs using 25 larvae $\mathrm{L}^{-1}$. Therefore, the lineage GIFT at density of 25.00 larvae $\mathrm{L}^{-1}$ is indicated for larval culture.
\end{abstract}

Keywords: GIFT. Oreochromis niloticus. Lineage selection. Thai.

\section{LINHAGENS DE TILÁPIAS DO NILO SUBMETIDAS À DIFERENTES DENSIDADES DE ESTOCAGEM NA LARVICULTURA}

RESUMO - Larvas de duas linhagens de tilápias do Nilo (Oreochromis niloticus) foram submetidas a diferentes densidades de estocagem. O ensaio foi conduzindo em um fatorial $2 \times 4$, sendo quatro densidades de estocagem $\left(6,25 ; 12,50 ; 18,75\right.$ e 25,00 ind. $\left.\mathrm{L}^{-1}\right)$, e duas linhagens (GIFT e Tailandesa). Larvas irmãs das linhagens Tailandesa e GIFT (4.000 ind.), foram distribuídas em 32 aquários com $8 \mathrm{~L}$ de água cada, de modo casualizado com quatro repetições cada. Por um período de 36 dias, as larvas foram mantidas em aquários providos de aeração constante e fotoperíodo natural. As variáveis limnológicas estiveram dentro da faixa adequada à espécie. Os dados foram interpretados por meio de ANOVA e para os efeitos densidade, utilizou-se Teste de Tukey. Quanto às variáveis biológicas, não houve interação entre linhagem e densidade. A linhagem GIFT apresentou melhor desempenho em comprimento total e biomassa para o $36^{\circ}$ dia. Dentre as densidades para cada linhagem os melhores resultados de comprimentos, peso e ganho de peso, foram para a densidade 6,25 ind. $\mathrm{L}^{-1}$, mas ao se utilizar 25 ind. $\mathrm{L}^{-1}$ ocorre aumento na biomassa e otimização do espaço utilizado. Portanto, indica-se as linhagens GIFT na densidade de 25,00 ind. $\mathrm{L}^{-1}$.

Palavras-chave: GIFT. Oreochromis niloticus. Seleção de linhagens. Tailandesa.

\footnotetext{
*Corresponding author

${ }^{1}$ Received for publication in 10/13/2014; accepted in 01/27/2016.

Paper extracted from master thesis of the first author.

${ }^{2}$ Department of Animal Science, Universidade Federal dos Vales do Jequitinhonha e Mucuri, MG, Brazil; emilia_tatiane@yahoo.com.br, marcelomattospedreira@gmail.com,mouraguilherme@yahoo.com.br, dayanekelly_98@hotmail.com, carlosotonibiologia7@bol.com.br.
} 


\section{INTRODUCTION}

Commercial lineages of Nile tilapia in Brazil have different origins. The Chitralada lineage, known as Thai, was developed in Japan, improved in Thailand and introduced in Brazil in 1996 (ZIMMERMANN, 1999). The GIFT (Genetically Improved Farmed Tilapia) lineage, produced in the Philippines, was introduced in Brazil in 2005 (FÜLBER et al., 2009). The Thai lineage has been the most cultivated and has been well accepted by Brazilian producers (TENÓRIO et al., 2012) because its high genetic potential (LUPCHINSKI JÚNIOR et al., 2008) and productive performance (BOSCOLO et al., 2001). The GIFT lineage has a higher yield potential compared to the Thai and Bouaké lineage (FÜLBER et al., 2010), indicating that the performance potential of the different lineages of tilapia is related to genetic factors (FÜLBER et al., 2010). However, regional researches evaluating their performance at different conditions of cultivation are needed, since some studies have shown the interaction between lineage and environment (EKNATH et al., 2007).

Although some lineages present better performance, the acquisition of these lineages by a producer does not ensure him a good yield, which can be influenced by the conditions of cultivation, such as the storage density (FÜLBER et al., 2010). The tilapia genetic variability may be high, requiring a proper reproductive management to avoid the negative consequences of inbreeding, i.e., a drop in the expected yield (MOREIRA et al., 2007).

Another essential factor for a successful fish farming is to establish the proper storage density, combining the maximum utilization of the space occupied by the fish, and optimizing production costs regarding the invested capital (MAINARDES PINTO et al., 2011; AYROZA et al., 2011). The increase in storage density reduces the growth of Nile tilapia, but improves the homogeneity of the larvae without affecting survival, sex reversal efficiency and the Fulton condition factor (TACHIBANA et al., 2008; 2009). Sanches and Hayashi (1999) reported that high densities can be used, resulting in smaller fry, but increasing the total biomass. However, the management should be proper for each condition (TACHIBANA et al., 2009), and the use of a recirculation system may be a form to support the growth of animals (TACHIBANA et al., 2008).

There is a demand for lineages with high production performance, therefore, the objective of this work was to evaluate the performance of two Nile tilapia (Oreochromis niloticus) lineages, GIFT and Thai, at different storage densities, during the larval culture.

\section{MATERIAL AND METHODS}

The experiment was conducted in the Aquaculture and Aquatic Ecology Laboratory of the UFVJM, Diamantina, MG, Brazil, in 2013, during 36 days, with tilapias from the EPAMIG of Leopoldina, MG.

The larvae $(4,000)$ from the Thai and GIFT lineages had mean weight of $14.0 \pm 1.0$ and $13.0 \pm 2.6$ $\mathrm{mg}$ and total length of $10,96 \pm 0.42$ and $10.54 \pm 0.28$ $\mathrm{mm}$, respectively, which were counted individually and transferred to 32 aquariums of $10 \mathrm{~L}$, with $8 \mathrm{~L}$ of water each, with constant aeration and natural photoperiod, in a recirculation system.

The larvae from the two lineages were subjected to four storage densities $(6.25,12.50$, 18.75 and 25.00 larvae $\mathrm{L}^{-1}$ with $50,100,150$ and 200 larvae per aquarium, respectively), distributed in a completely randomized design in a $2 \times 4$ factorial scheme (2 lineages x 4 densities), with four replications.

Feeding was performed with a powdered commercial feed containing $10 \%$ (max.) of moisture, $50 \%$ (min.) of crude protein, 4\% (min.) of ethereal extract, $6 \%$ (max.) of fibrous matter, 18\% (max.) of mineral matter, $5 \%$ (max.) of calcium and $0.15 \%$ (min.) of phosphorus, according to manufacturer's specifications. A reversion to male fish were performed, in order to simulate the commercial process of tilapia production, by adding $60 \mathrm{mg}$ of 17 $\alpha$ - methyltestosterone $\mathrm{kg}^{-1}$ in the given diet at a rate of $15 \%$ of the biomass, four times a day $(8: 00,11: 00$, 14:00 and 17:00h). Three animals from each replicate were randomly collected in the $12^{\text {th }}$ and $24^{\text {th }}$ day, euthanized with eugenol $\left(0.4 \mathrm{mg} \mathrm{L}^{-1}\right.$ for 10 minutes) according to the guidelines of the CONCEA (2013), to evaluate the weight (g) with an analytical scale (precision of $0.0001 \mathrm{~g}$ ) and the standard and total lengths with a digital caliper rule (precision of $0.01 \mathrm{~mm}$ ), obtaining then, the data that was used to calculate the weight gain and to adjust the amount of feed.

The excess of slurry was removed every two days, replacing the water removed (approximately $10 \%$ of the aquarium water volume).

The following physical and chemical parameters of water were evaluated before the aquarium cleaning at the $1^{\text {st }}, 6^{\text {th }}, 12^{\text {th }}, 18^{\text {th }}, 24^{\text {th }}$ and $36^{\text {th }}$ day: temperature $\left({ }^{\circ} \mathrm{C}\right)$, dissolved oxygen $\left(\mathrm{mg} \mathrm{L}^{-}\right.$ $\left.{ }^{1}\right)$, conductivity $\left(\mu \mathrm{S} \mathrm{cm}{ }^{-1}\right), \mathrm{pH}$, turbidity (NTU) and reduction-oxidation potential $(\mathrm{mV})$, using a Professional Plus probe. The nitrite, nitrate, ammonia and orthophosphate $\left(\mathrm{mg} \mathrm{L}^{-1}\right)$ were evaluated in the laboratory, following the methods of the "Standard Methods for the Examination of Water and Wastewater" (APHA, 1995).

The number of larvae of each sample unit was counted by the end of the cultivation cycle and the survival was evaluated. The biomass was evaluated by weighing all individuals of each aquarium. Then, 20 larvae per replicate were euthanized with a eugenol solution as described above and fixed with a 
$10 \%$ formaldehyde solution for subsequent biometrics (standard and total weight and length), which were evaluated with a Bel Mark M254-AI analytical scale (precision of $0.0001 \mathrm{~g}$ ) and a EDA digital caliper (accuracy of $0.01 \mathrm{~mm}$ ) respectively.

The subsequently evaluations were the Fulton condition factor $(\mathrm{K})=$ weight times 100 standard length $^{-3}$; weight gain $(\mathrm{g})=$ final mean weight $(\mathrm{g})$ initial mean weight $(\mathrm{g})$; and biomass gain $(\mathrm{g})=$ final biomass (g) - initial biomass (g).

The larvae means were subjected to a factorial arrangement (2 lineages $\mathrm{x} 4$ densities) completely randomized and Tukey test $(\mathrm{P}<0.05)$ for comparison between lineages and densities. Survival values were transformed into arcsine for statistical analysis, however the values in the tables were presented in percentages. The means and standard deviations of water quality data were calculated for characterization of the culture environment. Calculations were performed using the SAS 9.1 statistical software.

\section{RESULTS AND DISCUSSION}

The mean values of limnological variables for the evaluated days were: water temperature $\left(27.59 \pm 1.88 \quad{ }^{\circ} \mathrm{C}\right), \quad$ dissolved oxygen (7.68 $\left.\pm 0.74 \mathrm{mg} \mathrm{L}^{-1}\right), \mathrm{pH}(6.70 \pm 0.14)$, total ammonia $(1.71 \pm 1.80 \quad \mathrm{ppm}), \quad$ toxic ammonia $(0.0090 \pm 0.0095 \mathrm{ppm})$, nitrite $\left(0.01 \pm 0.04 \mathrm{mg} \mathrm{L}^{-1}\right)$, nitrate $\left(5.48 \pm 0.92 \mathrm{mg} \mathrm{L}^{-1}\right)$, orthophosphate $\left(1.53 \pm 1.03 \mathrm{mg} \mathrm{L}^{-1}\right)$, turbidity $(144.60 \pm 0.109 \mathrm{NTU})$ and conductivity $\left(252.96 \pm 110.52 \mu \mathrm{S} \mathrm{cm}^{-1}\right)$.

The water quality parameters in the experimental period were maintained in proper conditions for the tilapia development according to Kubitza (2011), who established values for recirculation systems (temperature 27 to $30^{\circ} \mathrm{C}, \mathrm{pH}$ 6.0 to 8.5 , dissolved oxygen above $4 \mathrm{mg} \mathrm{L}^{-1}$ and toxic ammonia below $0.2 \mathrm{mg} \mathrm{\textrm {L } ^ { - 1 }}$ ). The nitrite concentration mean was similar to that verified by Mercant et al. (2007) $\left(0.01 \mathrm{mg} \mathrm{L}^{-1}\right)$, while the nitrate concentration mean was higher than that verified by them $(0.13 \mathrm{mg})$, however within the values established by the resolution CONAMA 396/2008.

The use of powdered feed increases the amount of organic matter in the medium and when leached increases phosphorus levels (LOGATO, 2000). Excessive levels of phosphorus hinder the system, since it is a major contributor to eutrophication (HENRY-SILVA, CAMARGO, 2006). The orthophosphate levels verified under laboratory conditions in the experiment had no influence on larvae development. However, the powdered feed influenced the water turbidity and conductivity, with values above those considered suitable for larvae cultivation by Mercante et al. (2007). These authors stated that inorganic residues, organic matter from feeding and plankton cause an increased in turbidity and conductivity.

There was no interaction between lineage and density for the biological variables. There was no difference $(\mathrm{P}>0.05)$ between lineages in the $12^{\text {th }}$ and $24^{\text {th }}$ days for the verified parameters, while in the $36^{\text {th }}$ day there were differences $(\mathrm{P}<0.05)$ for biomass and total length, which were greater for the GIFT lineage (Table 1).

There was a difference in performance between lineages for the biological variables, with the GIFT lineage presenting better results $(\mathrm{P}<0.05)$ in total length and biomass on the $36^{\text {th }}$ day, and similar values $(\mathrm{P}>0.05)$ for the other parameters. The GIFT lineage presented a total length greater than the Thai when subjected to diets with different levels of crude protein, however, the total length for GIFT and Thai was similar with densities of 30,40 and 50 larvae $\mathrm{m}^{-3}$, results that were similar to those found by Fülber et al. (2010) and Fülber et al. (2009). The greater biomass found in the GIFT lineage is an important advantage, since according to Tachibana et al. (2008), it may provide higher profits.

There was no statistical difference by $12^{\text {th }}$ day for all evaluated parameters regarding the larvae density of the GIFT and Thai lineages (Table 2).

Table 1. Mean values and standard deviations of performance of larvae from two lineages of tilapia at the $12^{\text {th }}, 24^{\text {th }}$ and $36^{\text {th }}$ day of experiment: weight, weight gain (WG), standard length (SL), the total length (TL), Fulton condition factor (K), biomass (Bio) and survival $(\mathrm{Su})$.

\begin{tabular}{lcccccc}
\hline Parameters & \multicolumn{2}{c}{$12^{\text {th }}$ day } & \multicolumn{2}{c}{$24^{\text {th }}$ day } & \multicolumn{2}{c}{$36^{\text {th }}$ day } \\
\cline { 2 - 6 } & Thai & GIFT & Thai & GIFT & Thai & GIFT \\
\hline Weight $(\mathrm{mg})$ & $24.1 \pm$ & $22.1 \pm$ & $78.3 \pm$ & $71.0 \pm$ & $263.1 \pm$ & $283.0 \pm$ \\
& $6.3 \mathrm{a}$ & $4.3 \mathrm{a}$ & $27.8 \mathrm{a}$ & $27.0 \mathrm{a}$ & $76.5 \mathrm{a}$ & $89.3 \mathrm{a}$ \\
WG $(\mathrm{mg})$ & $11.1 \pm$ & $8.1 \pm$ & $65.4 \pm$ & $57.0 \pm$ & $250.1 \pm$ & $269.0 \pm$ \\
& $6.3 \mathrm{a}$ & $4.3 \mathrm{a}$ & $27.8 \mathrm{a}$ & $27.0 \mathrm{a}$ & $76.4 \mathrm{a}$ & $89.3 \mathrm{a}$ \\
SL (mm) & $9.84 \pm$ & $9.75 \pm$ & $13.73 \pm$ & $13.14 \pm$ & $20.18 \pm$ & $20.85 \pm$ \\
& $0.61 \mathrm{a}$ & $0.54 \mathrm{a}$ & $1.43 \mathrm{a}$ & $1.30 \mathrm{a}$ & $2.03 \mathrm{a}$ & $1.81 \mathrm{a}$ \\
\hline
\end{tabular}

Tilapia lineage factor means followed by different letters in the same row, for each day, differ statistically by the Tukey test $(\mathrm{P}<0.05)$. The sign - in table indicates that the biomass and survival were verified in $12^{\text {th }}$ and $24^{\text {th }}$ days for the two lineages. 
Table 1. Continuation.

\begin{tabular}{|c|c|c|c|c|c|c|}
\hline \multirow[t]{2}{*}{ Parameters } & \multicolumn{2}{|c|}{$12^{\text {th }}$ day } & \multicolumn{2}{|c|}{$24^{\text {th }}$ day } & \multicolumn{2}{|c|}{$36^{\text {th }}$ day } \\
\hline & Thai & GIFT & Thai & GIFT & Thai & GIFT \\
\hline \multirow[t]{2}{*}{ TL (mm) } & $11.95 \pm$ & $11.97 \pm$ & $16.72 \pm$ & $16.04 \pm$ & $24.21 \pm$ & $25.38 \pm$ \\
\hline & $0.77 \mathrm{a}$ & $0.63 \mathrm{a}$ & $1.86 \mathrm{a}$ & $1.67 \mathrm{a}$ & $2.34 b$ & $2.40 \mathrm{a}$ \\
\hline \multirow[t]{2}{*}{ K } & $2.45 \pm$ & $2.35 \pm$ & $2.87 \pm$ & $2.86 \pm$ & $3.09 \pm$ & $2.97 \pm$ \\
\hline & $0.29 a$ & $0.25 \mathrm{a}$ & $0.22 \mathrm{a}$ & $0.28 \mathrm{a}$ & $0.14 \mathrm{a}$ & $0.16 \mathrm{a}$ \\
\hline \multirow[t]{2}{*}{ Bio (g) } & - & - & - & - & $2.64 \pm$ & $2.96 \pm$ \\
\hline & & & & & $0.44 b$ & $0.62 \mathrm{a}$ \\
\hline \multirow[t]{2}{*}{$\mathrm{Su}(\%)$} & - & - & - & - & $83.69 \pm$ & $83.00 \pm$ \\
\hline & & & & & $6.05 \mathrm{a}$ & $10.63 a$ \\
\hline
\end{tabular}

Tilapia lineage factor means followed by different letters in the same row, for each day, differ statistically by the Tukey test $(\mathrm{P}<0.05)$. The sign - in table indicates that the biomass and survival were verified in $12^{\text {th }}$ and $24^{\text {th }}$ days for the two lineages.

Table 2. Mean values and standard deviations of performance of larvae from two lineages of tilapia submitted to different storage densities on the 12th day of experiment: weight, weight gain (WG), standard length (SL), total length (TL) and Fulton condition factor $(\mathrm{K})$.

\begin{tabular}{|c|c|c|c|c|c|}
\hline \multirow[t]{2}{*}{ Parameters } & \multirow[t]{2}{*}{ Lineage } & \multicolumn{4}{|c|}{ Densities (larvae L ${ }^{-1}$ ) } \\
\hline & & 6.25 & 12.50 & 18.75 & 25.00 \\
\hline \multirow[t]{2}{*}{ Weight (mg) } & Thai & $29.8 \pm 10.7$ & $27.0 \pm 6.8$ & $20.0 \pm 1.2$ & $19.5 \pm 2.8$ \\
\hline & GIFT & $26.0 \pm 5.8$ & $20.5 \pm 1.9$ & $21.8 \pm 4.1$ & $20.3 \pm 3.8$ \\
\hline \multirow{2}{*}{ WG (mg) } & Thai & $16.8 \pm 10.7$ & $14.0 \pm 6.8$ & $7.0 \pm 1.2$ & $6.5 \pm 2.8$ \\
\hline & GIFT & $12.0 \pm 5.8$ & $6.5 \pm 1.9$ & $7.8 \pm 4.1$ & $6.3 \pm 3.8$ \\
\hline \multirow[t]{2}{*}{$\mathrm{SL}(\mathrm{mm})$} & Thai & $10.36 \pm 1.09$ & $9.97 \pm 0.61$ & $9.70 \pm 0.22$ & $9.34 \pm 0.27$ \\
\hline & GIFT & $9.91 \pm 0.75$ & $9.67 \pm 0.20$ & $10.03 \pm 0.71$ & $9.38 \pm 0.26$ \\
\hline \multirow[t]{2}{*}{$\mathrm{TL}(\mathrm{mm})$} & Thai & $12.48 \pm 1.25$ & $12.46 \pm 0.98$ & $11.44 \pm 0.20$ & $11.43 \pm 0.43$ \\
\hline & GIFT & $12.43 \pm 0.85$ & $11.70 \pm 0.20$ & $11.94 \pm 0.87$ & $11.79 \pm 0.40$ \\
\hline \multirow[t]{2}{*}{ K } & Thai & $2.57 \pm 0.35$ & $2.66 \pm 0.32$ & $2.19 \pm 0.15$ & $2.38 \pm 0.14$ \\
\hline & GIFT & $2.59 \pm 0.15$ & $2.27 \pm 0.19$ & $2.12 \pm 0.09$ & $2.42 \pm 0.30$ \\
\hline
\end{tabular}

Density factor means followed by different letters in the same row differ statistically by the Tukey test $(\mathrm{P}<0.05)$.

In the $24^{\text {th }}$ day, the standard and total length, weight and weight gain of Nile tilapia larvae from the GIFT lineage subjected to a density of 6.25 larvae $\mathrm{L}^{-1}$ were greater $(\mathrm{P}<0.05)$ than those found for the densities of $12.5,18.7$ and 25.0 larvae $\mathrm{L}^{-1}$, which were similar to each other $(\mathrm{P}>0.05)$. The total and standard length, weight and weight gain of larvae from the Thai lineage at density of 6.25 larvae $\mathrm{L}^{-1}$ were greater than those found in the density of 25.0 larvae $\mathrm{L}^{-1}(\mathrm{P}<0.05)$. The values found for total and standard length, weight and weight gain for the Thai lineage at densities of 12.5 and 18.7 larvae $\mathrm{L}^{-1}$ were similar, not differing from values found for the densities of 6,25 and 25.0 larvae $\mathrm{L}^{-1}(\mathrm{P}>0.05)$.
Regarding the Fulton condition factor, larvae from GIFT and Thai lineages presented no significant differences related to the densities $(\mathrm{P}>0.05)$ (Table 3).

In the $36^{\text {th }}$ day, the total and standard length, weight and weight gain of larvae from the GIFT and Thai lineages subjected to a density of 6.25 larvae $\mathrm{L}^{-}$ 1 were greater $(\mathrm{P}<0.05)$ than those found for the density of 25.0 larvae $\mathrm{L}^{-1}$. The biomass of both lineages at density of 25,00 larvae $\mathrm{L}^{-1}$ was greater compared to those found in the density of 6.25 larvae $\mathrm{L}^{-1}(\mathrm{P}<0.05)$. Regarding the survival and Fulton condition factor, there was no difference between treatments of both lineages $(\mathrm{P}>0.05)$ (Table 4$)$. 
E. T. L. SILVA et al.

Table 3. Mean values and standard deviation of performance of larvae from two lineages of tilapia submitted to different storage densities on the $24^{\text {th }}$ day of experiment: weight, weight gain (WG), standard length (SL), total length (TL) and Fulton condition factor $(\mathrm{K})$.

\begin{tabular}{|c|c|c|c|c|c|}
\hline \multirow[t]{2}{*}{ Parameters } & \multirow[t]{2}{*}{ Lineage } & \multicolumn{4}{|c|}{ Densities (larvae $\mathrm{L}^{-1}$ ) } \\
\hline & & 6.25 & 12.50 & 18.75 & 25.00 \\
\hline \multirow[t]{2}{*}{ Weight (mg) } & Thai & $111.4 \pm 15.8 \mathrm{a}$ & $83.7 \pm 22.3 \mathrm{ab}$ & $70.8 \pm 21.5 \mathrm{ab}$ & $47.6 \pm 4.7 b$ \\
\hline & GIFT & $118.7 \pm 4.6 \mathrm{a}$ & $55.7 \pm 16.3 b$ & $53.9 \pm 5.7 b$ & $55.6 \pm 15.0 \mathrm{~b}$ \\
\hline \multirow[t]{2}{*}{ WG (mg) } & Thai & $98.4 \pm 15.8 \mathrm{a}$ & $70.7 \pm 22.3 \mathrm{ab}$ & $57.8 \pm 21.5 \mathrm{ab}$ & $34.6 \pm 4.7 b$ \\
\hline & GIFT & $104.7 \pm 46.0 \mathrm{a}$ & $41.7 \pm 16.3 b$ & $39.9 \pm 5.7 \mathrm{~b}$ & $41.3 \pm 15.0 \mathrm{~b}$ \\
\hline $\mathrm{SL}(\mathrm{mm})$ & Thai & $15.63 \pm 1.08 \mathrm{a}$ & $13.80 \pm 0.98 \mathrm{ab}$ & $13.32 \pm 1.09 \mathrm{ab}$ & $12.18 \pm 0.26 b$ \\
\hline TL (mm) & GIFT & $19.02 \pm 1.99 \mathrm{a}$ & $14.77 \pm 1.38 \mathrm{~b}$ & $15.17 \pm 0.46 b$ & $15.19 \pm 1.50 \mathrm{~b}$ \\
\hline \multirow[t]{2}{*}{$\mathrm{K}$} & Thai & $2.92 \pm 0.26 \mathrm{a}$ & $3.10 \pm 0.23^{\mathrm{a}}$ & $2.86 \pm 0.14 \mathrm{a}$ & $2.62 \pm 0.22 \mathrm{a}$ \\
\hline & GIFT & $3.07 \pm 0.12 \mathrm{a}$ & $2.87 \pm 0.34^{\mathrm{a}}$ & $2.76 \pm 0.29 \mathrm{a}$ & $2.75 \pm 0.28 \mathrm{a}$ \\
\hline
\end{tabular}

Density means followed by different letters in the same row differ statistically by the Tukey test $(\mathrm{P}<0.05)$.

Table 4. Mean values and standard deviation of performance of larvae from two lineages of tilapia submitted to different storage densities on the $36^{\text {th }}$ day of experiment: weight, weight gain (WG), standard length (SL), total length (TL), Fulton condition factor $(\mathrm{K})$, biomass (Bio) and survival $(\mathrm{Su})$.

\begin{tabular}{lccccc}
\hline Parameters & Lineage & \multicolumn{4}{c}{ Densities (larvae $\left.\mathrm{L}^{-1}\right)$} \\
\cline { 2 - 5 } & & 6.25 & 12.50 & 18.75 & 25.00 \\
\hline Weight $(\mathrm{mg})$ & Thai & $403.0 \pm 20.9 \mathrm{a}$ & $275.8 \pm 17.3 \mathrm{~b}$ & $193.4 \pm 11.5 \mathrm{~b}$ & $180.2 \pm 17.4 \mathrm{~b}$ \\
& GIFT & $443.0 \pm 84.9 \mathrm{a}$ & $278.1 \pm 42.3 \mathrm{~b}$ & $226.9 \pm 23.0 \mathrm{~b}$ & $184.2 \pm 15.9 \mathrm{~b}$ \\
WG $(\mathrm{mg})$ & Thai & $390.0 \pm 20.9 \mathrm{a}$ & $262.8 \pm 17.3 \mathrm{~b}$ & $180.4 \pm 11.5 \mathrm{~b}$ & $167.2 \pm 17.4 \mathrm{~b}$ \\
& GIFT & $428.9 \pm 84.9 \mathrm{a}$ & $264.1 \pm 42.3 \mathrm{~b}$ & $212.9 \pm 23.0 \mathrm{~b}$ & $170.2 \pm 15.9 \mathrm{~b}$ \\
SL $(\mathrm{mm})$ & Thai & $23.68 \pm 0.31 \mathrm{a}$ & $20.69 \pm 0.38 \mathrm{~b}$ & $18.30 \pm 0.28 \mathrm{c}$ & $18.04 \pm 0.43 \mathrm{c}$ \\
& GIFT & $24.11 \pm 1.64 \mathrm{a}$ & $20.59 \pm 1.12 \mathrm{~b}$ & $20.12 \pm 0.29 \mathrm{~b}$ & $18.60 \pm 0.67 \mathrm{~b}$ \\
TL $(\mathrm{mm})$ & Thai & $28.27 \pm 0.47 \mathrm{a}$ & $24.83 \pm 0.35 \mathrm{~b}$ & $22.13 \pm 0.46 \mathrm{c}$ & $21.62 \pm 0.52 \mathrm{c}$ \\
& GIFT & $29.38 \pm 1.76 \mathrm{a}$ & $25.50 \pm 1.43 \mathrm{~b}$ & $24.22 \pm 0.28 \mathrm{bc}$ & $22.43 \pm 0.76 \mathrm{c}$ \\
K & Thai & $3.03 \pm 0.05 \mathrm{a}$ & $3.12 \pm 0.29^{\mathrm{a}}$ & $3.15 \pm 0.13 \mathrm{a}$ & $3.05 \pm 0.08 \mathrm{a}$ \\
& GIFT & $3.11 \pm 0.07 \mathrm{a}$ & $3.15 \pm 0.09^{\mathrm{a}}$ & $2.77 \pm 0.19 \mathrm{a}$ & $2.85 \pm 0.07 \mathrm{a}$ \\
Bio $(\mathrm{g})$ & Thai & $1.94 \pm 0.10 \mathrm{~b}$ & $1.94 \pm 0.17 \mathrm{ab}$ & $2.620 .17 \mathrm{ab}$ & $3.32 \pm 0.35 \mathrm{a}$ \\
& GIFT & $2.15 \pm 0.42 \mathrm{c}$ & $2.64 \pm 0.42 \mathrm{bc}$ & $3.38 \pm 0.35 \mathrm{ab}$ & $3.66 \pm 0.32 \mathrm{a}$ \\
Su $(\%)$ & Thai & $81.00 \pm 4.00 \mathrm{a}$ & $79.25 \pm 13.63 \mathrm{a}$ & $86.00 \pm 4.00 \mathrm{a}$ & $88.50 \pm 1.50 \mathrm{a}$ \\
& GIFT & $74.50 \pm 12.50 \mathrm{a}$ & $86.50 \pm 5.50^{\mathrm{a}}$ & $91.00 \pm 3.00 \mathrm{a}$ & $80.00 \pm 15.00 \mathrm{a}$ \\
\hline
\end{tabular}

Density means followed by different letters in the same row differ statistically by the Tukey test $(\mathrm{P}<0.05)$.

The standard length values were similar for both lineages, differing from Fülber et al. (2010), who found greater length values for the GIFT.

There was no difference in weight gain between the GIFT and Thai lineages. Similar result was found by Fülber et al. (2009), evaluating three lineages of tilapia in tanks at densities of 12,20 and 28 larvae $\mathrm{m}^{-3}$ in the second phase of their experiment. The same authors found greater weight gain for the GIFT lineage at density of 40 larvae $\mathrm{m}^{-3}$ in the first phase of their experiment (31-58 days). However, compared to the Red lineage, the Thai had greater weight gain (MAINARDES-PINTO et al., 2011).

Overall, the Thai lineage has yield performance lower or equal to the GIFT lineage. Massago et al. (2010), evaluating four tilapia lineages (Bouaké, Thai, Supreme and GIFT), observed a better performance of the Supreme and GIFT lineages. These authors found no difference between the GIFT and Thai lineages in survival during the experiment and as well as for the weights and lengths at the $56^{\text {th }}$ and $84^{\text {th }}$ days. However, by the end of the experiment (112 days), the GIFT lineage had greater weight gain compared to the Thai. Boscolo et al. (2001), in the first phase of their experiment, found greater weight gain, feed conversion and survival for the Thai lineage compared to the common tilapia, and similar values regarding the Fulton condition factor.

The Fulton condition factor was similar between lineages $(\mathrm{P}>0.05)$, with values reaching 1.0 , denoting the proper conditions of the animals (MAINARDES-PINTO et al, 2011). Boscolo et al. (2001), also found similar values of Fulton condition factor comparing Thai and common tilapia. On the other hand, Mainardes-Pinto et al. (2011) found greater values of Fulton condition factor for Thai tilapia compared to Red tilapia.

Mainardes-Pinto et al. (2011), assessing the yield of Thai and Red tilapia, comparing the daily weight increase, final weight, Fulton condition factor and biomass, found better results for the Red lineage. However, the GIFT lineage has better yield potential and is considered superior compared to the Thai and Bouaké lineages (FÜLBER et al., 2010). Santos et 
al. (2007) also found that the GIFT lineage is more precocious, first reaching the its maximum production potential compared to the Thai.

Regarding the effect of density on the $24^{\text {th }}$ and $36^{\text {th }}$ day, the GIFT lineage presented greater weight, weight gain and total and standard length at the lower density (6.25 larvae $\left.\mathrm{L}^{-1}\right)$. Similar results were found by Fülber et al. (2009), in the second phase of their experiment with the same lineage. In the present work, the Thai lineage also presented a decrease in performance with increasing density. The lowest density presented greater weight, weight gain, standard length and total length $(\mathrm{P}>0.05)$ in the $24^{\text {th }}$ and $36^{\text {th }}$ day. Fülber et al. (2009) also found lower performance for the same parameters for this lineage in greater density. Ayroza et al. (2011) found that the daily weight gain of Nile tilapias reduces with increasing density. The decrease in yield in both lineages in the present work was attributed only to the increased density, since the water quality was maintained within the proper range of quality and homogeneous, due to the recirculation system. Tachibana et al. (2008), working with tilapia larvae under different storage densities maintained in a recirculation system, and water quality also within the proper range for the species, also reported decreased yield with increasing density, and not with decreasing water quality, corroborating the results found in this experiment.

The biomass had increased values with the increase in density for the GIFT and Thai lineages, as well as found by Marengoni (2006) and Ayroza et al. (2011) evaluating the increase of storage density of Nile tilapias in tanks.

There was no influence of the storage density on the survival of both lineages. Fülber et al. (2009) also observed no influence of density in the survival of Thai and GIFT lineages. Ayroza et al. (2011) evaluated Nile tilapia at different densities, which also had not differed in survival. Tachibana et al. (2008) and Tachibana et al. (2009) also found no significant changes in Fulton condition factor for Nile tilapia larvae at densities of 1, 3, 5 and 7 larvae $\mathrm{L}^{-1}$, similar to the results found for the GIFT and Thai lineages in the present work.

\section{CONCLUSION}

The GIFT lineage presented better performance regarding the total length and biomass compared to the Thai lineage. Therefore, the GIFT lineage is recommended, at a density of 6.25 larvae $\mathrm{L}^{-1}$, for better weight gain, or at 25.00 larvae $\mathrm{L}^{-1}$ for greater biomass after 36 days. However, for the later stages of the tilapias, additional experiments should be performed.

\section{AKNOWLEDGEMENTS}

To the Research Support Foundation of the State of Minas Gerais (FAPEMIG) and to the Brazilian Northeast Bank (BNB) for financial support, to the Coordination for the Improvement of Higher Education (CAPES), and to the National Council for Scientific and Technological Development $(\mathrm{CNPq})$ for granting scholarships.

\section{REFERENCES}

APHA - American Public Health Association. Standard methods for examination of water and wastewater.19 ed. Washington: EPS Group, 1995. $1268 \mathrm{p}$

AYROZA, L. M. S. et al. Custos e rentabilidade da produção de juvenis de tilápia-do-Nilo em tanquesrede utilizando-se diferentes densidades de estocagem. Revista Brasileira de Zootecnia, Viçosa, v. 40, n. 2, p. 231-239, 2011.

BOSCOLO, W. R. et al. Desempenho e características de carcaça de machos revertidos de tilápias do Nilo (Oreochromis niloticus), linhagens tailandesa e comum, nas fases inicial e de crescimento. Revista Brasileira de Zootecnia, Viçosa, v. 30, n. 5, p. 1391-1396, 2001.

CONAMA, Resolução. 396 de 07 de abril de 2008. Conselho Nacional do Meio Ambiente-CONAMA, v. 396, 2008.

CONCEA, Diretrizes da Prática de Eutanásia do Concea. Brasília/DF, 2013. Ministério da Ciência, Tecnologia e Inovação Conselho Nacional de Controle de Experimentação Animal - CONCEA, 2013, 54 p.

EKNATH, A. E. et al. Genetic improvement of farmed tilapias: Composition and genetic parameters of a synthetic base population of Oreochromis niloticus for selective breeding. Aquaculture, Amsterdam, v. 273, n. 1, p. 1-14, 2007.

FÜLBER, V. M. et al. Desempenho comparativo de três linhagens de tilápia do Nilo Oreochromis niloticus em diferentes densidades de estocagem. Acta Scientiarum: Animal Sciences, Maringá, v. 31, n. 2, p. 177-183, 2009.

FÜLBER, V. M. et al. Desempenho produtivo de três linhagens de tilápia-do-Nilo (Oreochromis niloticus) alimentadas com dois níveis de proteína. Acta Scientiarum: Animal Sciences, Maringá, v. 32, n.1, p. 77-83, 2010.

HENRY-SILVA， G. G.; CAMARGO, A. F. M. Efficiency of aquatic macrophytes to treat Nile tilapia pond effluents. Scientia Agricola, Piracicaba, 
v. 63 , n. 5, p. $433-438,2006$.

KUBITZA, F. Tilápia: tecnologia e planejamento na produção comercial. 2. ed. Jundiaí, SP: Acqua Supre Com. Suprim. Aqüicultura, 2011. 316 p.

LOGATO, P. V. R. Forma física da ração. In: VIEIRA, E. A. Nutrição e alimentação de peixes de água doce. Viçosa: Editora Aprenda Fácil, 2000. 87-106 p.

LUPCHINSKI JÚNIOR, E. et al. Avaliação da variabilidade das gerações G0 e F1 da linhagem GIFT de tilápia do Nilo (Oreochromis niloticus) por RAPD. Acta Scientiarum. Animal Science, Maringá, v. 30, n. 2, p. 233-240, 2008.

MAINARDES-PINTO, C. S. R. et al. Desempenho produtivo da tilápia tailandesa e da tilápia vermelha da Flórida estocadas em diferentes densidades, em tanques-rede instalados em viveiros. Boletim do Instituto de Pesca, São Paulo, v. 37, n. 3, p. 225 234, 2011.

MASSAGO, H. et al. Crescimento de quatro linhagens de tilápia Orechromis niloticus. Revista Acadêmica Ciências Agrárias e Ambientais, Curitiba, v. 8, n. 4, p. 397-203, 2010.

MARENGONI, N. G. Produção de tilápia do Nilo Oreochromis niloticus (Linhagem Chitralada), cultivada em tanques-rede, sob diferentes densidades de estocagem. Archivos de Zootecnia, Córdoba, v. 55 , n. 210 , p. $127-138,2006$

MERCANTE, C. T. J. et al. Qualidade de água em viveiro de tilápia do Nilo (Oreochromis niloticus): caracterização diurna de variáveis físicas, químicas e biológicas. Bioikos, Campinas, v. 21, n. 2, p. 79-88, 2007.

MOREIRA, A. A. et al. Variabilidade genética de duas variedades de tilápia nilótica por meio de marcadores microssatélites. Pesquisa Agropecuária Brasileira, Brasília, v. 42, n. 4, p. 521-526, 2007.

SANCHES, L. E. F.; HAYASHI, C. Densidade de estocagem no desempenho de larvas de tilápia-doNilo (Oreochromis niloticus L.), durante a reversão sexual. Acta Scientiarum. Animal Sciences, Maringá, v. 21, n. 3, p. 619-625, 1999.

SANTOS, V. B. et al. Avaliação de curvas de crescimento morfométrico de linhagens de tilápia do Nilo (Oreochromis niloticus). Ciência e Agrotecnologia, Lavras, v. 31, n. 5, p. 1486-1492, 2007.

SAS Institute INC. 2002 - 2003. Statistical analysis system. Release 9.1. (Software). Cary. USA.
TACHIBANA, L. et al. Densidade de estocagem de pós-larvas de tilápia-do-Nilo (Oreochromis niloticus) durante a fase de reversão sexual. Boletim do Instituto de Pesca, São Paulo, v. 34, n. 4, p. 483 488, 2008

TACHIBANA, L. et al. Densidades de estocagens de pós-larvas de tilápia-do-Nilo submetido à inversão sexual. Bioikos, Campinas, v. 23, n. 2, p. 77-82, 2009.

TENÓRIO, I. V.; SOARES, M. D. C. F.; LOPES, J. P. Desempenho comparativo em tanques-rede de três linhagens da tilápia do Nilo - Oreochromis niloticus: comum, chitralada e mestiço. Revista Biotemas, Florianópolis, v. 25, n. 1, p. 65-72, 2012.

ZIMMERMANN, S. Incubação artificial: técnica permite a produção de tilápias do Nilo geneticamente superiores. Panorama da Aquicultura, Rio de Janeiro, v. 9, n. 4, p. 15-21, 1999. 